\title{
Implanted-pacemaker-induced dysrhythmia and its management
}

\author{
S. J. JACHUCK \\ B.Sc, M.B., B.S.
}

Regional Cardiovascular Unit, Newcastle-upon-Tyne General Hospital

\section{Summary}

Five cases of implanted-pacemaker-induced dysrhythmia are described and factors precipitating such dysrhythmias are discussed.

The efficacy of practolol in the treatment of such dysrhythmias is shown and its use as a prophylactic antidysrhythmic agent has been suggested.

A NUMBER of artificial-pacemaker-induced dysrhythmias has been described. Quinidine, lignocaine and procainamide are known to be beneficial in the treatment of such dysrhythmias. The use of practolol is described as a valuable anti-dysrhythmic measure in the management of artificial-pacemaker-induced dysrhythmias.

\section{Case reports}

Case 1

A 65-year-old diabetic lady had been treated with Saventrine since 1965 for her heart block. In September 1971 she developed frequent StokesAdams attacks for which a ventricular inhibited intracardiac pacemaker was implanted. Within $24 \mathrm{hr}$ of implantation she developed frequent ventricular extra-systoles which responded to procainamide. Subsequently she developed lignocaine-resistant ventricular tachycardia (Fig. 1) which responded to $20 \mathrm{mg}$ of practolol, given intravenously. As the ventricular extra-systoles reappeared she was treated with practolol $100 \mathrm{mg}$ twice daily and she has had no dysrhythmia since.

\section{Case 2}

A ventricular inhibited pacemaker was implanted in the axilla of a diabetic man for heart block with syncopal attacks. He had suffered from heart block for 2 years and was managed medically with Saventrine. Six weeks after the implantation, he developed supraventricular tachycardia (Fig. 2). His dysrhythmia was treated with practolol $100 \mathrm{mg}$ given at 8-hr intervals. No dysrhythmia has been noted since.

\section{Case 3}

A ventricular inhibited pacemaker had to be implanted in a 71-year-old lady as Saventrine failed to restore her haemodynamic instability due to

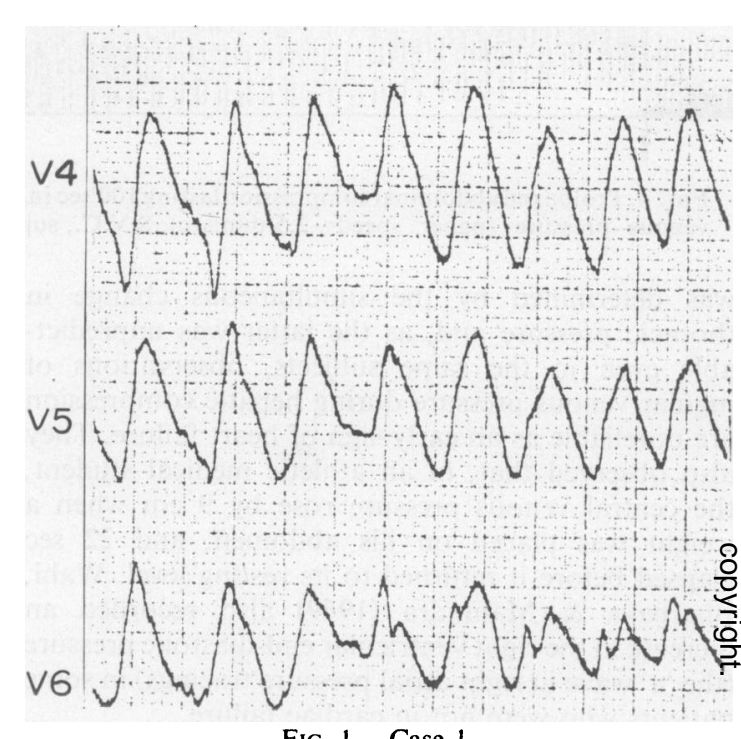

Fig. 1. Case 1.

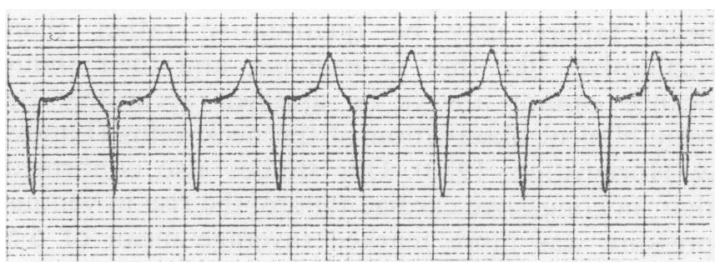

Fig. 2. Case 2.

heart block. A month after the implantation of the pacemaker, she developed frequent ventricular extra-systoles which inhibited the pacemaker (Fig. 3). This produced syncope. She was treated with practolol $100 \mathrm{mg}$ at 8 -hr intervals. Since the institution of this therapy she had no dysrhythmia and no further syncope.

\section{Case 4}

A man who had had a fixed rate pacemaker implanted 4 years before for complete heart block developed 'palpitations' and syncopal episodes. An 


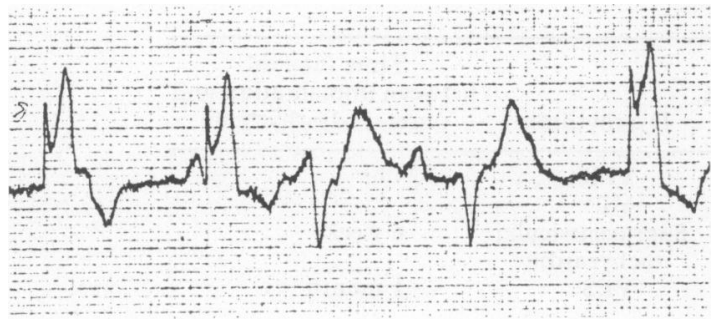

Fig. 3. Case 3.

electrocardiogram revealed frequent ventricular extra-systoles (Fig. 4). He was treated with practolol $100 \mathrm{mg}$ twice a day. Since the commencement of practolol therapy, he has had no syncopal attacks and subsequent electrocardiograms showed no extra-systoles.

\section{Case 5}

Soon after the implantation of a fixed rate pacemaker in the axilla, frequent ventricular extra- systoles were observed (Fig. 5). These were treated with practolol and he has showed no other dysrhythmia since.

There was no evidence of recent cardiac infarction in any of the above patients. All the pacing systems were found to be functioning satisfactorily. Saventrine was discontinued after commencement of artificial pacing. Satisfactory pacing was achieved in all the above cases after controlling the dysrhythmia. All the above patients are now symptomfree.

\section{Discussion}

Since the first successful resuscitation of the heart in ventricular standstill by external electric stimulation by Zoll (Zoll, 1952), artificial pacemakers have been acclaimed as a most useful contribution in the treatment of heart block, and approximately 1800 patients in Britain are at present being treated with implantable mercury-cell pacemakers. Apart from the other recognized complications, fatal dysrhythmias

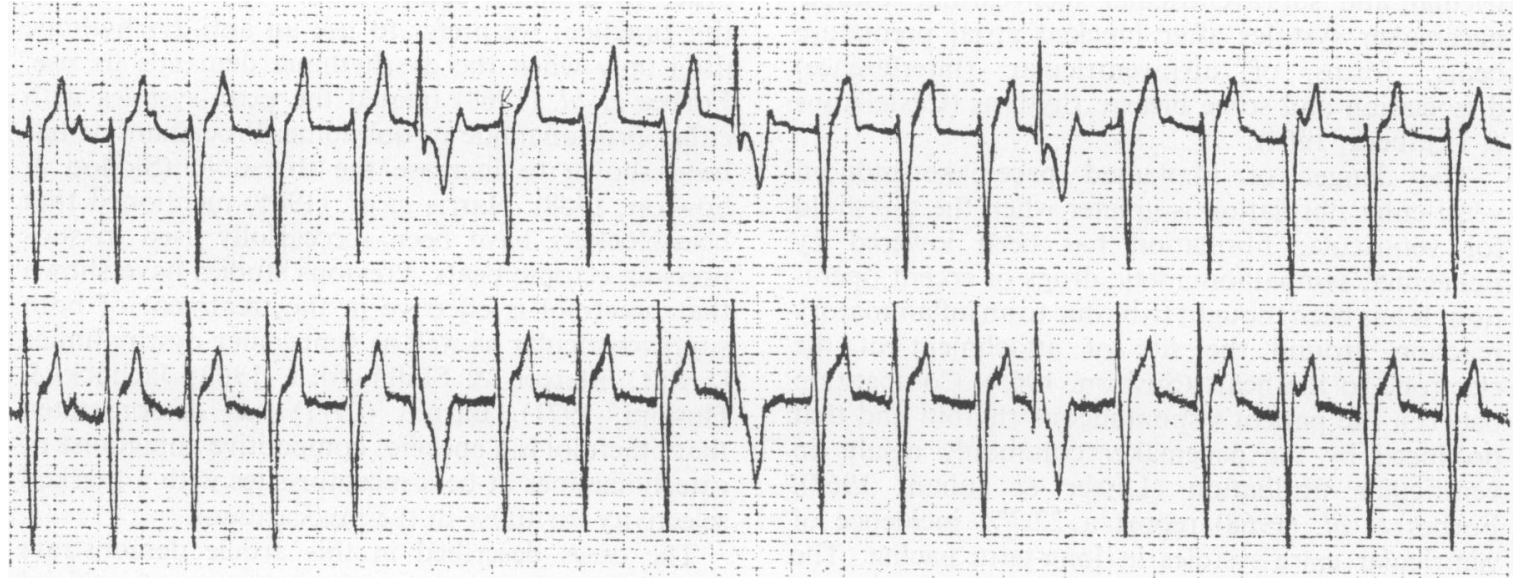

Fig. 4. Case 4.

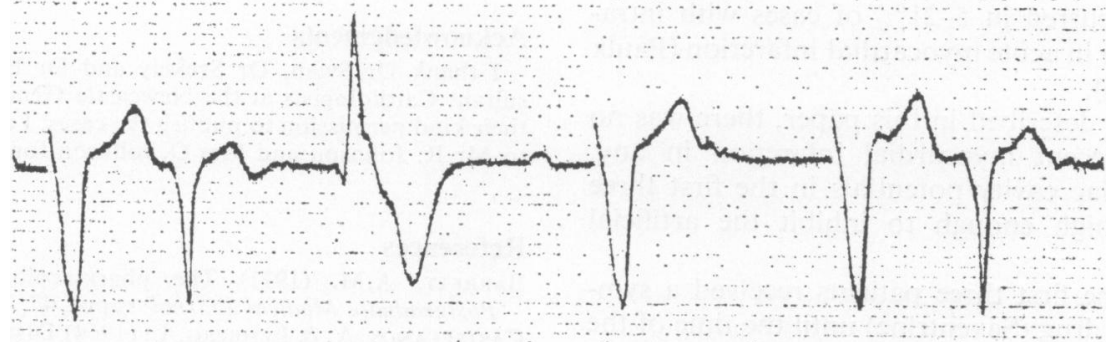

Fig. 5. Case 5 . 
TABLE 1

\begin{tabular}{|c|c|c|c|c|c|}
\hline Case no. & $\begin{array}{l}\text { Type of } \\
\text { pacemaker }\end{array}$ & $\begin{array}{l}\text { Pacemaker } \\
\text { rate }\end{array}$ & $\begin{array}{l}\text { Intracardiac } \\
\text { cavity potential } \\
(\mathrm{mV})\end{array}$ & Dysrhythmia & $\begin{array}{l}\text { Time interval } \\
\text { between implantation and } \\
\text { onset of dysrhythmia }\end{array}$ \\
\hline 1. & $\begin{array}{r}\text { Ventricular } \\
\text { inhibited }\end{array}$ & 86 & 6 & \multirow{3}{*}{$\begin{array}{c}\text { VES } \\
\text { VT } \\
\text { Supraventricular } \\
\text { tachycardia } \\
\text { VES }\end{array}$} & $24 \mathrm{hr}$ \\
\hline 2. & $\begin{array}{l}\text { Ventricular } \\
\text { inhibited }\end{array}$ & 73 & 9 & & 6 weeks \\
\hline 3. & $\begin{array}{l}\text { Ventricular } \\
\text { inhibited }\end{array}$ & 72 & 10 & & 1 month \\
\hline $\begin{array}{l}4 . \\
5 .\end{array}$ & $\begin{array}{l}\text { Fixed rate } \\
\text { Fixed rate }\end{array}$ & $\begin{array}{l}70 \\
70\end{array}$ & $\begin{array}{l}\text { Not done } \\
\text { Not done }\end{array}$ & $\begin{array}{l}\text { VES } \\
\text { VES }\end{array}$ & $\begin{array}{c}4 \text { years after } \\
\text { Soon after implantation }\end{array}$ \\
\hline
\end{tabular}

VT, Ventricular tachycardia; VES, ventricular extra-systoles.

are known to be induced by the artificial pacemaker. Sowton (1965) has described a higher death rate in those with artificial pacemaker-induced ventricular fibrillation. A rare dysrhythmia resembling ventricular fibrillation has been described after implantation of a cardiac pacemaker, due to repetitive ventricular firing. With the advent of 'demand' pacemakers, such complications seem to be rare. Other associated dysrhythmias are parasystole, ventricular and supraventricular tachycardia, 'escape' pacemaker systoles after blocked atrial premature beats, forms of atrioventricular (interference) dissociation and some bizarre rhythms (Castellanos \& Lemberg, 1964).

The danger of implanted pacemaker-induced ventricular fibrillation is greater when the threshold for ventricular fibrillation has been lowered by ischaemia, sympathomimetic drugs or recent operation. It has been thought to be due to an inflammatory reaction around the site of attachment of the electrode to the heart (Sowton, 1965). Competition between the patient's spontaneous rhythm and that produced by the pacemaker commonly results in ventricular fibrillation (Lasser \& Julian, 1968). Forbes et al. (1968) report a $22.7 \%$ incidence of ventricular extra-systoles in long-term pacing. The majority of the patients developed the extra-systoles in the first $48 \mathrm{hr}$ after implantation. In a series of sixty patients, ventricular fibrillation occurred in five patients and one developed ventricular tachycardia while in hospital (Sowton, 1965). Ventricular fibrillation occurred in $5-21 \%$ of cases with intracardiac pacing in acute myocardial infarction (Paulk \& Hurst, 1966).

In the cases described in this paper, there was no evidence of recent myocardial infarction in any. The intracardiac cavity potentials in the first three patients are high enough to inhibit the artificial pacemaker.

Although the first three patients received a sympathomimetic drug (Saventrine) until the time of the pacemaker implantation, only the first case developed dysrhythmia within $24 \mathrm{hr}$. The other two developed dysrhythmia after one month. The fifth case developed dysrhythmia soon after surgical implantation of the pacemaker (Table 1). The appearance of dysrhythmia 4 years after the implantation in the fourth case, proves that the dysrhythmogenic activity may remain dormant for a variable period.

Chatterjee, Harris \& Leatham (1969) suggested using lignocaine infusion followed by oral procainamide or quinidine, as a prophylactic measure, in order to diminish competition. We do not follow this practice: we prefer to use an anti-dysrhythmic drug only when the dysrhythmia demands its use. Forbes et al. (1968) treated the extra-systoles with either procainamide or quinidine. Procainamide has been shown to increase the threshold (Siddon Sowton, 1968). Harris et al. (1965) mentioned that beta-blockers have been successfully used in suppressing ectopic beats. Previous studies have shown that practolol is effective in the treatment of both supraventricular as well as ventricular dysrhythmias (Jewitt, Mercer \& Shillingford, 1969; Jachuck \& Husaini, 1971). Barrett (1971) has demonstrated that practolol is a specific, competitive antagonist of catecholamines at beta-receptor sites with a marked selectivity for those in the myocardium.

The cases described in this article demonstrate the efficacy of practolol in the treatment of artificial pacemaker-induced dysrhythmias and also suggests its use as a prophylactic measure, in a dysrhythmiaprone patient.

\section{Acknowledgments}

I thank Dr Swan, Dr Szekely and Dr Henderson, Consultant Cardiologists at the Newcastle General Hospital for their kind permission to publish the cases. I am also indebted to Mr R. Johnson and Mrs O. Johnson for their assistance.

\section{References}

BARretT, A.M. (1971) The pharmacology of practolol. Postgraduate Medical Journal, suppl. 47, 7.

Castellanos, A. \& Lemberg, L. (1964) Disorders of rhythm appearing after implantation of synchronised pacemaker. British Heart Journal, 26, 747. 
Chatterjee, K., Harris, A. \& Leatham, A. (1969) The risk of pacing after infarction and current recommendations. Lancet, ii, 1061.

Forbes, W., Green, G.D., Shaw, G.B. \& Bain, W. (1968) Long-term transvenous cardiac pacing with ChardakGreatbach (Medtronic) pacemaker. British Medical Journal, 3, 2.

FriedberG, C.K. Diseases of the Heart, 3rd edn. W. B. Saunders, London.

Harris, A., Bluestone, R., Busby, E., Davies, G., Leatham, A., SidDons, H. \& Sowton, E. (1965) The management of heart block. British Heart Journal, 27, 469.

JACHUCK, S.J. \& HUSAINI, M.H. (1971) Intravenous practolol. British Medical Journal, 4, 298.

JewitT, D., MerCer, C.J., \& Shillingford, J.L. (1969) Practolol in the treatment of cardiac dysrhythmias due to acute myocardial infarction. Lancet, ii, 227.
LASSER, B.W. \& Julian, D.G. (1968) Artificial pacing in management of complete heart block complicating acute myocardial infarction. British Medical Journal, 2, 142.

PAulK, E.A. \& Hurst, J.W. (1966) Complete heart block in acute myocardial infarction. American Journal of Cardiology, 17, 695.

Siddon, H. \& Sowton, E. (1968) Cardiac Pacemakers, 2nd printing. Charles Thomas, Springfield, Ill.

Sowton, E. (1965) Artificial pacemaking and sinus rhythm. British Heart Journal, 27, 331.

Zoll, P.M. (1952) Resuscitation of the heart in ventricular standstill by external electric stimulation. New England Journal of Medicine, 246, 768.

Leading Article (1971) British Medical Journal, 4, 442. 